\title{
Racial taxonomy in genomics
}

\author{
Catherine Bliss* \\ Brown University, Africana Studies, 155 Angell St Box 1904, Providence, RI 02912, United States
}

\section{A R T I C L E I N F O}

Article history:

Available online 28 July 2011

Keywords:
Canada
USA
Race
Genomics
Taxonomy
Reflexivity
Biosociality
Inclusion

\begin{abstract}
A B S T R A C T
This article examines the reflexive, biosocial nature of genomic meaning making around race, drawing on discourse analysis of 732 articles on genomics and race published from the years 1986-2010, in-depth interviews with 36 of the world's most elite genomics researchers, interviews with 15 critics, policymakers, and trainees involved in debates over race, and participant observation at a core genotyping facility that specializes in ancestry estimation. I reveal how biomedical researchers identify with, value, and make sense of the taxonomies they construct. My analysis goes beyond a consideration of instrumental rationales to analyze the experiential and political motivations that shape how researchers get involved in racial ethical dilemmas. I theorize taxonomic practice as a reflexive form of biosociality, a conscious shaping of social notions about biology and race to produce a future that researchers themselves want to live in. I demonstrate how reflexive biosociality paradoxically leads researchers to advance social explanations for race while investing in genomics as a solution to racial quandaries.
\end{abstract}

(c) 2011 Elsevier Ltd. All rights reserved.

\section{Introduction}

In recent decades, the urge to understand how humans vary from one another at the level of DNA has produced biomedical investigation into the genomics of race. The study of genomics has resulted in a dizzying back-and-forth stance on race-first denial of any racial difference at the level of DNA, to later focusing attention on these differences (Reardon, 2005). Across the field of genomics, leading labs have tested the biological validity and medical utility of race with each newly invented biomarker platform and informatic program (Bliss, 2012). International genome projects like the Human Genome Project, Human Genome Diversity Project, and International HapMap Project have gone from avoiding race wholesale to embracing it; sampling DNA by common lay taxonomies (Bliss, 2009). In 2005, the first race-based medicine was put to market (Kahn, 2008; Lee, 2007), creating a stir in the genomic community. Examining all our DNA to understand the common illnesses and variation that affect humanity, genomics uses patterns of shared ancestry within the human species to redefine human taxonomy and question the limits of prior notions of difference (Fujimura \& Ramagopalan, 2011).

This renewed interest in the biology of race is surprising given that representatives of an array of natural and social sciences, including leading geneticists, once whole-heartedly denounced prior racial biomedicine. For over half a century, international

\footnotetext{
* Tel.: +1 718208 7124; fax: +1 4018631704

E-mail address: Catherine_Bliss@brown.edu.
}

governing bodies and academic organizations elaborated statements, policies, and theories defining race in terms of social and political dynamics only (see AAA, 1998; Duster, 2003; UNESCO, $1950,1952)$. In an age when it seems academic common sense that race as a category is socially constructed, how is a genomics of race possible?

This article explores the resurgence of racial biomedicine in terms of reflexive biosociality: researchers' conscious effort to create analytics that contribute to a future they themselves want to live in. Genomicists who experience the social reality of race have a vested interest in scientifically "getting race right." They oscillate between policy frameworks and experiential rationales to fashion taxonomies that square with dominant values about minority inclusion and medical equality. Most use a racial taxonomy when they believe it can help racial minorities. These reflexive representation processes allow researchers to produce a social order that benefits themselves and their kin, while offering avenues for racebased sociality that make sense in the current redress-focused context. This leads to a science in which researchers simultaneously posit race as real but not real. Researchers paradoxically advance social explanations for race, while asserting genomics as a plausible solution to racial dilemmas.

\section{Genomics at the Surface}

In the past decade, genomic investigation into race has spawned a notable public controversy (Braun, 2002; Hunt \& Megyesi, 2008). A vigorous debate followed President Clinton's celebratory remarks 
on the first draft of the human genome that "one of the great truths to emerge from this triumphant expedition inside the human genome is that in genetic terms, all human beings, regardless of race, are more than 99.9 percent the same" (Office of the Press Secretary, 2000). While leading genomicists rallied to make corroborating statements (Angier, 2000; Chandler, 2001), consensus on the genome's proof-positive meaning for race faltered as early as 2001 when a drug editor at the New England Journal of Medicine claimed that race corresponded with the genomics of drug response. A number of researchers published contrasting opinions in the field's leading biomedical journals (McLeod, 2001; Rothstein \& Epps, 2001; Schwartz, 2001; Wilson et al., 2001; Wood, 2001), while journals hosted special issues devoted to proving the un-biological nature of race (see, for example, Nature Genetics December 2001; The Pharmacogenomics Journal March 2001; Scientific American June 2003). By mid-decade, major biomedical journals had developed editorial recommendations for reporting with racial classifications (Litt, 2001; Nature Genetics, 2001, 2004; Rivara \& Finberg, 2001; Steele, 2002; Winker, 2004). While most genomicists who have discussed the meaning of race have made strong statements against its biological basis, a few prominent researchers have maintained that there are serious biological aspects of race that should not be ignored.

Questions of how genomic researchers should operationalize race in efforts to include minorities in biomedical research and public health frame the field's controversy. U.S. federal policy mandates that researchers use federal classifications to structure all publicly funded research. This policy emerged in the late 1980s, when the Department of Health and Human Services commenced an aggressive campaign to implement the federal race standards designated in the Office of Management and Budget's Directive No. 15 (Stoto, Behrens, \& Rosemont, 1990:51). Issued in 1977, Directive No. 15 required all government offices and agencies to monitor patterns in racism, segregation, and racial disparities in voting practices by tabulating American Indian or Alaska Native, Asian or Pacific Islander, Black, and White participation (OMB, 1978). After a hard-won battle to convince the federal government that women, children, and minorities were also ignored by the one-size-fits-all health system, in 1986, the National Institutes of Health began drafting its first minority inclusion policy (Epstein, 2007). Being conscious of race was to become a norm and standard across biomedicine, with corollary support in the wider public (Bliss, 2009). Seven years later, the National Institutes of Health issued the Revitalization Act, a statute setting strict guidelines for the inclusion and surveillance of women and minorities in clinical research and clinical trials (NIH, 1993). In 1993, the Center for Disease Control and Prevention also drafted "Use of Race and Ethnicity in Public Health Surveillance" statement (CDC, 1993, also see CDC, 1999). By 1998, the Food and Drug Administration ruled that all new drug applications must "present effectiveness and safety data for important demographic subgroups, specifically gender, age, and racial subgroups" (FDA, 1998) and the Surgeon General's Office began administrating its Healthy People decennial program by Directive No. 15 classifications (HHS, 1998). Since the turn of the century, these health agencies have revitalized these policies with implementation mandates sensitive to the unique challenges faced by researchers working in their domains $(\mathrm{NIH}$ 2000, 2001; FDA 2003, 2005). Thus, researchers must take federal research inclusion aims into account from the earliest stages of research design.

Continued controversy despite clear policies on how researchers should work with the federal taxonomy, and ostensive closure of prior debates, has motivated some social scientists to question how genomic researchers conceptualize and apply race in the lab and clinic. Recent empirical investigation has shown that researchers of various ranks operate without clear definitions of racial variables and that they fail to critically examine their inconsistent practices (Fullwiley 2007a, 2007b; Hunt \& Megyesi, 2008; M'Charek, 2005; Tutton, 2007; Tutton \& Corrigan, 2004). Interviews with genome project leaders and journal editors have shown that the field's gatekeepers are reluctant to see critical race policy as important to their role (Outram \& Ellison, 2006; Smart et al., 2008) and they ignore the political dimensions of their work (Reardon, 2005). Ethnographies of leading pharmacogenomics laboratories and population-based biobanks have also shown that researchers uncritically align federal inclusionary standards with genomic population categories to produce a system of research wherein research populations are stratified by race and then targeted for race-based cures (Fullwiley, 2007a, 2007b, 2008; Montoya, 2011; Smart et al., 2008; Tutton, 2007; Tutton \& Corrigan, 2004; Whitmarsh, 2008). Some studies have suggested that lead investigators allow market interests to instrumentally guide their research (Fullwiley 2008; Nelson, 2008a, 2008b). Asking researchers directly about their definitions of race has provoked uncomfortable silences and bashful laughter, to no avail of a critical working model (Fullwiley, 2007a, 2007b; Tutton, 2007; Tutton \& Corrigan, 2004; on working models of race, see Morning, 2009). Two researchers have been shown to overtly draw on their personal values about race to guide the classification process (Fullwiley, 2008; Nelson, 2008a).

The present study, consisting of interviews with many of the field's leaders, finds that genomic elites are conscious of their role as knowledge gatekeepers and are proactively aligning their taxonomies with broader ethical values on race. As members of a biomedical system that rewards inquiry into minority health and health disparities, these researchers use their positions to instigate research that may shape the world's knowledge about race (Moore, 2008). Though genomic researchers view variation from a medical perspective, they nevertheless interpret the world around them from within a matrix of racialized values, conventions, and understandings. Researchers reflexively draw from memories of prejudice and discrimination to create an antiracist biomedicine, and interpret and implement their values-based framework through the lens of racial justice that dominates biomedicine today. They enact their beliefs about prejudicial treatment, racism, and racial inequality through their inquiry into and representation of race and their use of racial taxonomy.

These processes of representation can be viewed in terms of biosociality. At the turn of the century, Rabinow predicted the rise of a mode of intersubjectivity where "groups formed around [genomic classifications would] have medical specialists, laboratories, narratives, traditions and a heavy panoply of pastoral keepers to help them experience, share, intervene in, and 'understand' their fate" (Rabinow, 1996:244). Biology-based intersubjectivity has indeed advanced as states have progressively applied genomics in the administration of health welfare (Epstein, 2007; Petryna, 2002; Rose, 2007). The U.S. government's move to publicly fund health disparities research has entwined with its incorporation of genomic technologies into America's basic research institutions (Bliss, 2012). Epstein (2007) has shown that the fortification of inclusionary policies ensures that the new genomic citizenship will continue to be constructed within a racialized system of health governance. Bolnick et al. (2007) have described the ways consumer markets intersect with state efforts to produce race-targeted products, services, and research. Abu El Haj (2007) argues that biosociality around race is increasingly attuned to the logic of risk that dominates genomic biomedicine.

Building on this research, I place researchers and their subjectivity at the center of biosociality. I show that genomic elites make choices that contradict a strict biologically objective rationale, 
because they identify with the effects of those choices. They fiercely criticize race and just as fiercely defend its role in medical research, because they see race as being biologically questionable yet socially salient. In this sense, this genomic biosociality is reflexive biosociality. Researchers consider official taxonomies and the discourses of race at hand in critical ways, because they see themselves as the stewards of the public's vitality (Fullwiley, 2008; Rose, 2007). They increasingly engage in minority inclusion campaigns and genomic health disparities research to promote their racial values and to create a social system that can best serve themselves and their loved ones.

This is not to say that careerism, financial considerations, and other forms of self-interest are not entwined with reflexive biosociality. Genomic elites are agents of biotechnology development, pharmaceutical research, and clinical medicine, and are thus concerned about profitability and political survival in complex ways. Yet, the practical world in which these scientists operate is inextricable from a social world eager for innovative solutions to social problems (Rabinow, 2003). Researchers' iterative assertions of preoccupations with youth and family present a specific kind of biosociality that relies on personal enthusiasm and open moralizing about the work at hand (Shapin, 2008). Just as patients and research subjects have become politicized in the contemporary context of engaged health activism (Novas and Rose, 2000), biomedical researchers are interpreting their surroundings through a politically charged set of values and using their positions to shape the future.

This model for understanding biomedical research is different than prior understandings of biosociality in two important ways. Rabinow devised the concept to represent an emergent kind of sociality formed around new biotechnologies. According to him, individuals begin to socialize around the new forms of biological knowledge and medical expertise that increasingly populate the public sphere. As people put greater weight on the biomedical significance of their existence, sociality becomes infused with "bio" interpretations (Rabinow, 1996). Others have followed Rabinow in specifically focusing on social action pertaining to health consumers and patients (Novas, 2006; Novas \& Gibbons, 2007; Rose, 2007). By contrast, my conceptualization of biosociality apprehends social action pertaining to researchers, who are also the stakeholders and beneficiaries of new knowledge and expertise. As such, reflexive biosociality shows us that biosociality is not simply about the production of new subjectivities and intersubjective ties around new objects of biomedical research. Rather, the subjects of biomedicine, biomedical researchers themselves, also craft their subjectivity around new objects of research. Researcher identities are produced dialectically with the racial knowledge that they produce.

Reflexive biosociality is also different from prior conceptualizations, because it tackles social formations taking shape between emergent and residual epistemes (Williams, 1991). Moving beyond the idea that biosociality is a mere matter of new disease categories displacing old forms of taxonomy, my conceptualization shows that concepts of race also shape emergent frameworks. In fact, individuals seize on new biotechnologies in order to create more robust notions of race, gender, and other longstanding, institutionalized classification systems. This conceptualization, thus, provides a more dynamic understanding of the objects around which people biosocialize and the modes by which they biosocialize.

Though recent ethnographies of genomics have edged toward taking scientist subjectivity and epistemic intersections into account, none have fully explored these aspects. While Reardon's (2005) research into the Human Genome Diversity Project has illuminated how project scientists' ignorance about racial inequality and privilege led to the project's demise, and Montoya
(2011) and Smart and colleagues (2008) have shown that racial ignorance has informed the ways that scientists and editorial gatekeepers operationalize official standards, none have examined the manifest political choices that scientists make or the values they consciously draw on. Nelson (2008a, 2008b) and Fullwiley (2007a, 2007b, 2008) have characterized how individual scientists have intentionally shaped the broader public biosociality around race. For example, Nelson has revealed the ways one African-American entrepreneurial scientist has influenced African-American biosociality with his commercial framing of blackness and diaspora (Nelson, 2008a, 2008b). Studying a Latino scientist that manipulates data to produce Latino-specific pharmacogenomics interventions, Fullwiley has described the minority scientist as a spurious "shepherd" for other minorities (Fullwiley, 2008:726). Yet, neither addresses patterns across biomedical research. Studying a collection of the field's most influential scientists-minority and otherwise racialized-I show that researchers across a field reflexively use their science to attempt to produce social change.

\section{Data and methods}

This analysis is based on semi-structured, hierarchical interviews with 36 widely distributed members of the field's professional elite. This research was supported by NSF grant SBE-0727360 with IRB approval from the New School of Social Research. It is part of a larger study on genomic racial biomedicine that involved content analysis of 732 articles on genomics and race published from the years 1986-2010, in-depth interviews with 51 researchers and social critics involved in debates over race, and participant observation at a core genotyping facility that specializes in ancestry estimation. Though subjects are stationed globally and all conduct multi-sited research, all interviews were conducted in subjects' Canadian or U.S. headquarters. Of the present subsample, all but five researchers were between the ages of 35 and 55. Five are women. I do not provide racial tabulation for reasons discussed below. Since these researchers are publicly recognizable, I obtained consent to using subjects' names and institutional affiliations.

The researchers constitute a purposive core-set sample of senior and lead scientists listed on the publications of the major global genome projects and international epidemiological cohort studies of the genomic era, and inaugural reports of the field's defining technological breakthroughs (see Collins, 1992). They are the founding directors and lab chiefs at the world's leading sequencing centers, chief officials of the field's professional societies, and editors of the most venerated venues for genomic research publication. Most are also high-ranking members of leading pharmaceutical or biotechnology firms. Because genomics is a highly concentrated capital-intensive science, these researchers control the vast majority of resources in the field. Beyond the high profile human variation and biomedical studies for which they are famous, these researchers are also responsible for the field's basic inquiry into plant and animal genomics, the genomics of microorganisms, and synthetic genomics.

Between April 2007 and June 2008, I conducted digitally recorded interviews at a number of locations in and around researchers' North American headquarters. I invited researchers to participate in the study with a brief email noting my interest in race and human variation after the Human Genome Project. I was aware that any mention of race would likely bring out a measure of impressions management around the subject's racial values, so I geared my interview questions to the practices in each researcher's lab, used records of each researcher's activities to learn about their social and biomedical responsibilities, and observed many in an array of work-related contexts. Interviews consisted of 
a 45-120 min formal interview. I supplemented interviews with observation of the technologies used in individual labs and visits to surrounding genotyping facilities that provide services to these researchers. Post-interview observation included up to $8 \mathrm{~h}$ of nonrecorded shadowing and dialogue. All recorded material was transcribed verbatim in its entirety and manually coded.

Rather than seek a truth-value to their claims, I take themes in self-presentation itself as a valuable kind of evidence (Goffman, 1959). Narrations, especially ones that involve recollections of the past, are always rooted in contemporary concerns (Danto, 1985). Therefore, rather than communicate a verifiable truth, these narrations signal broader normative trends, ethical frameworks, and moral dilemmas that presently affect individuals. In what follows, I present the ways genomicists draw on memory and marshal past experience to "account for themselves" (Hermanowicz, 2009) and "organize their complex pasts to present a coherent self-identity" (Hermanowicz, 1998). I triangulate researcher narrations with their personal histories and present protocols to show how elite genomic researchers are conceiving the biosocial future.

\section{Research findings}

I found that, contrary to the overwhelmingly race-critical tone of the field's mainstream debate, researchers have been reinvestigating the likelihood of a biological basis for race with each new genomic advance (Bliss, 2012). Also, leading researchers are deeply ambivalent about the role of racial taxonomy in genomic medicine that is not directly focused on redefining race. A large majority explained that racial taxonomy is useful for inclusionary purposes, respecting the self-determination of minority research subjects, and addressing health disparities. Yet, an equally large majority strongly criticized its use in the lab and clinic.

Still, the most intriguing pattern in my study of elite genomicists was their preoccupation with the subjective and political implications of their research. Scientists answered all of my questions about basic research practices with thick descriptions of their personal motivations, social concerns, and political interests. The narrations that follow reveal how scientists reflexively make sense of their research by considering a range of social and ethical issues that arise in a biosocial world. In doing so, racial experiences and values entwine practical demands for research taxonomies to create a powerful commitment to biologically redefining race and the social field.

\section{Thinking through the present with the past}

Before asking a single question from my interview schedule, many researchers I met shared personal stories of their first racial experiences. They relayed emotionally elaborate tales of childhood events, workplace encounters, and people along the way who changed the way they thought about race and variation and made them want to know "what makes people different," "what was the basis of why people are in different groups," and "why I was in the race that I am." This should not be surprising, since genomicists, like everyone else, undergo processes of racialization. Yet, the consistent intensity revealed in this array of interviews shows that, when faced with the task of explaining their work, researchers use past experiences to make sense of their present-day practices and present day findings to make sense of their own racial pasts.

Some confided having a deep-seated childhood curiosity about race as a result of growing up in the segregated Southern U.S. Typical among the Southern researchers I met was a heightened sensitivity to the difficulties in making sense of racial discrimination. As Howard University's Georgia Dunston stated: ...it seemed if we could understand what made [blacks] different then maybe we could be all alike, so that the problems-especially the negative things with folks who were in groups that seemed to be bad (as we were told)-if we understand what made us this way, maybe we could change them.

Dunston went on to found America's premier genomic institute focused on African-American health: Howard's National Human Genome Center. The National Human Genome Center's mission statement reads:

The mission of the National Human Genome Center is to explore the science of and teach the knowledge about DNA sequence variation and its interaction with the environment in the causality, prevention, and treatment of diseases common in African-American and other African Diaspora populations (Howard University, 2011).

Armed with this explicitly racial outlook, Dunston has attempted two genome sequencing projects targeted toward African-American DNA research: the Genomic Research in African-American Pedigrees Project and the Genomic Research in the African Diaspora Project. She has frequently been quoted as arguing for a genomics that focuses on African-American health and the relationship of racial experiences to genetics (see, for example, Dunston, 2011; Goldstein \& Weiss, 2003). Her story exposes how racial perplexity can serve as the foundation for subsequent biomedical inquiry and one's biosocial vision of the genomicist's role. Likewise, it suggests that researchers use situated rationales to think through their career paths. Understanding race is not just about biomedicine; it is about being able to make sense of one's own life.

Researchers who grew up outside of de jure segregation stressed the impact de facto segregation had on their future work. One population scientist told of his entry into a minority-dominated urban university and his successive commitment to inner-city public health. Another researcher explained seeking out fellowships in African-American communities before widening his basic research to studying the differences in immigrant African and African-American populations. Among the MD/PhD researchers I met, stories of medical service in de facto segregated zones were rampant. As Joanna Mountain of the Google-backed personal genomics company 23andMe phrased it, these researchers saw themselves as "concerned about the impact of racism first" before entering the field. Their present construction and application of human taxonomy is bound to concerns about the best way to represent people and address the social and medical needs of communities in which they have worked and lived. In doing so, researchers build a biosocial solution to the social and political problems of inequality and the conceptual problems of race.

All but one of the elite researchers in this study revealed the effect familial racial experiences have had on racial beliefs. University of California-San Francisco's Esteban Burchard, an asthma researcher who self-identifies as Latino, related how his mother's experiences impacted his own:

My mom was really hard working and my grandmother also worked very hard. She was very smart and I always thought, I still think to this day, that she didn't get her due credit because of her racial background. I still believe that if she was white she would have been much more successful, but she looks black.

Burchard later described how his mother foretold that his "lighter skin" privilege would take him out of the racial ghetto he grew up in:

And she told me once when I was very young, I must have been like seven, she said, "You are going to be able to go places where 
I could never go." She taught me about this permeability. I use it today. Because of who you are and your abilities, you can go through certain scenarios back and forth, kind of like a fish going through a big net. Some fish can go back and forth while other ones will get caught. And she told me very young that I would be able to do that. And she was right.

Burchard and other minorities spoke about including racial minorities in their research, and studying minority health, as a way of leveling the social playing field that created trauma for themselves and their own families. Researchers also spent time talking about their children, their children's experiences, and the kind of world they envisioned for them. They described their efforts at understanding genomic variation as a battle for redefining race. Thus, for personal and social reasons, the idea of relegating its inquiry into the dustbin of history is not an option. Rather, researchers look to biosocial stewardship through genomics.

Though, in the interests of maintaining race as an open question, I did not ask them to convey a racial affiliation or discuss the racial backgrounds of their family members, most of the researchers I interviewed offered up this information without prompt. One quarter told me that they were "multiracial" or belonged to a multiracial family. Members of multiracial families, including white scientists who have children that identify as nonwhite, openly discussed the influence of racial experiences in their present day lives, showing family photos and reflecting on their children's racial identities and experiences, further evincing the role of personal matters as one aspect of racial sense making.

Nearly half of those I interviewed reported Jewish origins and discussed race in terms of anti-Semitic experiences. These Jewish researchers were quick to link past anti-Semitism to present day racism affecting themselves and North American minorities. Some recounted racial discrimination in their own lives such as being set apart from others at school, while others explained their ancestors' hardships in Nazi Europe and Eastern European pogroms. The history of twentieth century eugenics and Nazi "racial hygiene" was important to these researchers' worldviews and pedagogies. For example, two Harvard researchers, Joel Hirschhorn and David Altshuler, have created a lecture on the school's broad history of racial abuses for their Human Genetics course. Others have taken part in the passage of protective policies such as the Genetic Information Non-Discrimination Act in order to protect themselves and their loved ones from potential harm.

Finally, a number of participants in this study were foreign born. These researchers were vocal about their acculturation and racialization experiences in North America. All but one of the foreign born researchers I interviewed were married to U.S. or Canadian citizens and had multicultural, if not multiracial, families. Those who have been ascribed a minority racial identity or have family members who have been racialized as minorities were particularly critical of the racist legacies of genetics and wanted to, as the National Human Genome Research Institute's Charles Rotimi put it, "inform the whole notion of identity" with their research. They revealed a heightened self-consciousness based on a deep suspicion of official taxonomies in a variety of contexts. Like their colleagues doing comparative research on immigrant populations and domestic racial minorities, foreign-born researchers felt it was their job to problematize commonsense taxonomies, but they also mobilized racial taxonomy in the interest of minority inclusion. Thus, they interpreted their work on race as socially advantageous to minorities around the world.

All in all, these biomedical elites present the relevance of racial memory and experience to everyday scientific practice. Each views the world and their taxonomic responsibilities through a historically contingent racialized lens. Reflections on their own identities and the classifications most salient to their personal lives are at the forefront of the way they speak about race. Researchers interpret their own struggles as they think through the very object of their research.

\section{Putting experiences and values to work}

Nearly everyone I interviewed referred to the troubled history of eugenics at least once during our conversations. Researchers also avidly denounced the racist values that shaped biomedicine prior to eugenics. Many referred to the study of "black diseases," "Negro problems," and the networks of political prestige and investment that fueled past research. Several researchers spoke specifically about Johann Blumenbach's "varieties," Carl Linnaeus's taxonomy, and the hegemonic reach of scientific racism over biomedicine and society today. Instead of relegating these ideas to the distant past, researchers talked about the shadow they have cast over contemporary biomedicine. Though they described eugenics as, in the words of one genomicist, their "intellectual ancestry," they optimistically spoke of these legacies as something that could be rectified through better genomic definitions of race. In order to have the biosocial future they envision, these researchers believe that biosocial medicine is necessary. Researchers see the need for the field to utilize its technology to solve any dispute about race's real biological meaning (see, for example, Burchard et al., 2003; Kumar et al., 2010; Tang et al., 2005).

All the researchers I interviewed devise mechanisms for promoting minority inclusion in genomic research. They agree with the government's premise that biomedical research has historically been Eurocentric. They revile the lackadaisical attitude toward minority recruitment in all biomedical research, but are especially concerned that genomics guide other fields in matters of inclusion. Rotimi offered critical comments about a study that claimed that it couldn't include minorities exemplify this sentiment:

Over about a year or two years, periodically they only called in one or two families.

And somebody says, "We can't or we don't want to participate," -but forgetting that the reason maybe you're not successful is that you don't understand this community. You don't have somebody that they can relate to, to participate in a study like this. And of course you may also have a history of collecting this kind of information and never going back to them with your results. And so why should they come again?

Rotimi desires more minority representation in the subject and researcher populations. He implies that a minority subject's interests will be better attended to if the researchers share similar background experiences. His strategy creates a dual project of recruiting scientists of color and creating a biosocial group in the image of the recruiter. At the National Institute of Health, Rotimi launched a center dedicated to genomic research into racial health disparities. The Center for Research on Genomics and Global Health (formerly the Center for Genomics and Health Disparities) scans the genomes of people of African descent for biomarkers relevant to major diseases like diabetes and hypertension in studies that are minority-led according to this anti-Eurocentrism vision.

Another genome project founder explained this principle in the reverse. Luigi Luca Cavalli-Sforza associated lingering Eurocentrism with the high representation of European Jewish ancestry among genomic colleagues, saying Ashkenazi Jews were over-studied at the expense of even Sephardic Jews. In the process of collecting samples for the Human Genome Diversity Project, Cavalli-Sforza attempted to focus on undersampled populations like indigenous South and East Asians. Strategies like these show how genomic researchers operationalize inclusion, both in terms of who comprises the field and gets researched. 
To avoid Eurocentrism, when leading a project, researchers often start by oversampling racial minorities. David Hinds, formerly of Perlegen Sciences, the main industry-based participant in the International HapMap Project, explained:

If you just sample people at random in the United States, you've got 7\% Asians and 9\% African-Americans and 6\% Hispanic people. But with those groups you're not going to have enough of them to be able to detect small genetic effects, and most of your analyses are going to end up being restricted to the subset of European people.

Perlegen's multi-population studies have oversampled by classifications akin to the Census taxonomy (see, for example, Hinds et al., 2005; Patil et al., 2001).

Genomicists also try to be inclusive by creating drug studies and biotechnologies that target minorities. They pride themselves on their politically sensitive relationships with groups that they can use as proxies for the larger population, while emphasizing their ability to move resources directly to minority groups. As Rick Kittles, an expert on African populations and CEO of a genetic genealogy company, said:

When I go into West Africa people see themselves in what I do and I make sure of that. I'm very sensitive, even in the studies that we do in the African-American populations. I think that there is a level of fraternity and actual egos that create barriers to sample collection.

Kittles has been extremely successful at building a large African populations database for use in his research at the University of Chicago and his company African Ancestry, Inc. Kittles was one of several who critiqued prior sciences for sampling DNA from minority groups and giving nothing in return.

It is important to note that pharmacogenomics and biotechnological development, where scientists cross the for-profit and nonprofit divide, can lead to a narrow, profit-based definition of biosocial reciprocity. For example, instead of giving back tangible resources, African Ancestry gives customers a Certificate of Ancestry and provides online resources, such as book lists and embassy information, for customers to connect with their "genetic cousins" in Africa. Clinical trials may give no resources beyond basic tests to understand a drug's safety and efficacy. In all cases, political reputations mediate researchers' ability to gain access to research subjects and amass larger markets. Researchers play on these differences to promote their own vision of biosociality. How researchers build their ethics and interpret their social responsibility is thus deeply entwined with social and political considerations such as the coherence between subject and researcher identity and racial cognizance, but also economic concerns like profitability.

Genomicists also use subject self-identification as a standard sampling procedure, because they believe this best respects minority self-determination. Subject self-identification is the first step in interfacing a research population. Regarding multipopulation studies, Harvard Medical School's David Reich explained:

We ask them: "What is your self-described ancestry?" And I have a list of things that they can fill out. They will say, "European American," "African-American," "Latino American," "Japanese American," etc.

For studies focused on one population, researchers alternately vet participants by having them identify their grandparents' origins. Researchers said they prefer self-identification (marking boxes, writing in responses, or both) to eyeballing (registering a subject's ancestry by the researcher's impression), because it best respects the research subject's dignity. They were especially vocal about minority self-identification, most using the language of "selfdetermination" or refusal to "tell people who they are" to describe its significance to the research process. Researchers spoke of selfidentification as a subject's right in light of the heinous legacy of racist racial biomedicine, though as critics have argued selfidentification according to a pre-selected list also sediments the autonomy of the scientist to racially categorize (Outram \& Ellison, 2006) and to create taxonomy without government oversight (Bliss, 2012).

Approaching their biomedical choices reflexively, these researchers feel that subject self-identification is enacted in the interest of antiracist values filtered through the constraints of genomic protocols. Subject self-identification introduces overall field-wide inconsistency thereby reducing biomedical rigor. In other words, there is no scientific benefit to promoting this approach. Instead, recalling how they would like to be treated (either as a minority or as they imagine a minority would), these researchers said that engaging minority groups on their own terms is more important than creating an objective research protocol. Researchers believe maintaining a subject self-identification policy will build trust and lasting relationships with the communities they feel deserve the utmost attention.

\section{Tackling health disparities and race}

While most researchers do not claim to know the exact root of health disparities, all believe genomics will increasingly play a central role where other fields have failed. Though researchers might want to start with strict genomic populations, with minority health research there is an even greater impetus to make sampled populations, genomic populations, and target markets correspond. So while these scientists use self-devised taxonomies, they increasingly seek answers to racial health disparities in dominant cultural terms. In fact, their sense of what comprises the category of "minority" and "minority health" rests on the patterns of social stratification that the U.S. government aims to address with its Census taxonomy. I consistently heard scientists shuttle between their own preferred terms, the government's terms, and the color-coded terms that they avoid when designing their own studies. Slippages like these point to greater conceptual flimsiness between what is perceived as biological versus genomic, and between goals for research inclusion and inclusion in public health.

Despite their discomfort with extramural notions of race, scientists make exceptions for use of racial taxonomy as a heuristic in research that covers health disparities. Computational biologist Mark Daly explained their broader systemic concerns:

We can substitute racial labels in a purely genetic study with actual hard data now, but we can't do that when we're looking completely across the board and in terms of how people are treated and what access they have had to medical care and what access they have had to early life advantages, nutrition and so forth.

Scientists like Daly overwhelmingly supported the use of racial taxonomy in measures of the biological effects of racial discrimination (see, for example, Risch, 2006; Torres \& Kittles, 2007).

Due to their commitments to minority health, nearly all the scientists who spoke out against propagating a genetic concept of race said they do use a racial taxonomy in their clinical or epidemiological work. For example, Elad Ziv of the University of California-San Francisco stated: 
This is the data that [epidemiologists] have. This is also how people think of themselves to some degree. So you can get this information and it turns out it correlates with a lot of diseases, for various reasons, as a functional thing.

Genomicists emphasized the need to calibrate classifications to the wider system of health research, describing a vast epidemiological body of research that precedes genomics. Many of the researchers I interviewed celebrate the field's ability to join basic research with this racialized discourse. Other genomicists expressed the belief that racism creates a biological feedback loop in the body, therefore racial taxonomy can have direct biological significance. Some argued that "the lifespan of discrimination and racism based on skin color," as Kittles put it, justified the use of racial heuristics.

I found that researchers are adopting social epidemiological methods to add to their genomic health disparities research. New lines of funding and collaboration that governments have formed with labs that work on the biology of race support this biosocial framework. For instance, in the U.S., the National Institutes of Health partners with "Historically Black Universities," and in 2010 launched a global African genome project that will require new biotech and pharmaceutical innovations from these very experts. While genetic epidemiology has often bridged the biological and social gap in dealing with racial health disparities, the push to expand genomics to encompass health disparities research is happening at its primary molecular labs and sequencing centers. Harvard and Massachusetts General Hospital's Center for Genomics, Disparities and Vulnerable Populations, Howard's National Human Genome Center, and the National Human Genome Research Institute's National Intramural Center for Research on Genomics and Global Health are some examples. These centers make up a network of labs dedicated to using gene-environment models, where race is placed at the center of genomic inquiry. The limit of this new research model is that genomic research into environmental factors focuses on lifestyle and health behaviors, stress, and other factors pertaining to individual health rather than the social environment or sociological processes of health.

Elite researchers are also fluent in a social theory idiom, even comfortable with sociological jargon. Time and time again, they emphasized that "race is a social construct" and, as one company website has phrased it, race "includes both a cultural and biological feature of a person or group of people" (DNAPrint Genomics, 2008). As I observed, a large majority of these researchers were actively deliberating racial descriptors in the lab and for institutional policy. Social and racial justice was important to the vision they have for the field's development. For example, the National Institutes of Health Director Francis Collins said, for an ideal study, in addition to socioeconomic status, educational level, and other contextual information, "realistically you would want to know for every participant, okay, what do they self identify with as far as race or ethnic group?" Collins and others have made public calls for expanding the biomedicine's scope in an epidemiological direction, further fusing genomic methods with a specific biosocial vision of an antiracist future (see, for example, Manolio, Bailey-Wilson, \& Collins, 2004). Again, the limits of this vision are that researchers oversimplify what "social" means in their accounts of social construction. As one scientist put it, "race is the social construction of who you are," evincing an individualized concept of identity construction that ignores structural inequality and processes of racial ascription.

\section{Correcting taxonomies}

Since the field has yet to be surveyed on their use of official taxonomies, and the publication record reveals myriad systems, I decided to investigate how taxonomies get made. Remarkably, despite the mandate to use official classifications, I found researchers devise their own classifications based on their personal views about race and racial dialogue with their peers. I also found researchers to be critical about the classification process and, thus, resistant to the government's attempts at oversight (Bamshad \& Guthery, 2007). By correcting taxonomies, researchers show an engagement in political debates that goes far beyond the genomic job description. They manage taxonomies in ways that are not simply driven by objective scientific interests.

The researchers interviewed indicated that, unless they are involved in a consortium project, they are the ones who determine the taxonomies that structure their sampling procedures. Researchers showed me rosters with which they delimited subject self-identification. They use classifications believed to be racially sensitive and try to develop a consistency within their own lab's sampling protocols. I even observed this replacement of official standards in two government-based labs.

Despite this autonomous posture, these researchers pointed to the ways their choices have been shaped by external factors. First, as discussed above, epidemiological studies use taxonomies that fit with prior epidemiological systems. Generally, epidemiologists seem more open to a racially approximate taxonomy, such as a continental system, if it means their research will be integrated with that body of research (Bliss, 2012). Second, researchers examine their classifications in light of broader political considerations. When I asked researchers to explain what constitutes a "best" descriptor, contrary to a strict data-driven type of response all spoke of political sensitivity. This was true for scientists more comfortable with a priori descriptors, such as genomic epidemiologists, and more statistically focused scientists who avoid using a priori categories. For example, Lynn Jorde, the Populations and ELSI Co-Chair of the International HapMap Project and a developer of fundamental research methods, said:

I avoid using [certain terms] because it immediately incites in some individuals negative feelings. . . Like the term Caucasian has this interesting history that has its roots in some real racist thinking, as I am sure you know. I think $99.9 \%$ of the people who use the term have no idea that it does. It's kind of like the term Gypsy. Most people use the term Gypsy not realizing that again it comes from a-well, it was assigned to "those people" (to Egypt) and it might be insulting in some cases. And I think the same is true with Caucasian.

Most think that geographic terms make superior descriptors, because they are good at imparting the primacy of the environment in genomic processes, and less politically charged than other kinds of terms. They believe that geographic terms like "Sub-Saharan African" provide a neutral alternative to colorized terms like "black." They are aware that these terms have a social context and use them to meet their biosocial needs.

Importantly, all but one of these leading researchers spoke against standardization in the field. As the Broad Institute's David Altshuler said: "If you agreed on labels, that would kind of be problematic, as you'd be endorsing them in some way." Though stressing the importance of minority inclusion, these researchers feel that they can and should be trusted to make the call respective to each research problem. They maintain a heuristic approach to sampling, because they believe genomic knowledge of the human is more accurate than social forms.

Taking a reflexively biosocial stance, these researchers explained the need to correct public misconception about government standards. The leader of the private effort to map the human genome, Craig Venter, said: 
The ideal is that we all try to use our power, our positions if we have any, to try and influence the world around us. For me it is very hard to be in truly a modern society looking at the past fore-history of our species and not to be upset, be ashamed of it, extremely bothered by it.

Venter was sure that genomics would eventually produce a medically relevant taxonomy that people would biosocialize around. The University of Washington's Michael Bamshad similarly refused what he saw as a flawed social rationale: "It makes no sense to me as to why I would group a people based on skin pigmentation alone." Bamshad's research has attempted to prove the variability of correspondence between genomic and racial taxonomy depending on the markers used to measure human difference, and provide policy recommendations for moving beyond the U.S. federal taxonomy (see, for example, Bamshad, 2005; Bamshad et al., 2003). As a member of the editorial board of the American Journal of Medical Genetics and co-author of a leading biomedical textbook, Medical Genetics, he has been an influential figure in the debate over racial taxonomy. All but one of the elites I interviewed had participated in a public conference on race policy and genomics in the year leading up to our first meeting. Most of them had organized such conferences in the past and were involved in ongoing efforts to bring the field's knowledge to minority community forums. These researchers display a conscious intent to use genomics to dispel racial myths.

Attention to the implementation of official taxonomies simultaneously reveals the most powerful taxonomies in a given historical moment and the way their application hinges on a biosocial ethic that researchers themselves construct. Researchers must identify with such standards or find them reflective of their current value system in order to put them into practice. Beliefs about whom researchers should research will produce alternate taxonomies, the basis for future standards. Shifting standards will dialectically infuse social experiences that researchers have within the field and across society, creating new frameworks for interpreting race.

\section{Conclusion}

Taking researcher biosociality seriously permits a novel analysis of genomics, biomedicine, and race. The interplay between experiences, values, and taxonomies reveals racial knowledge to be negotiated with more complex interests than appear at first glance. Genomic elites study race, in part, because they feel that knowledge about race is valuable to them personally and socially. They use minority inclusion, social epidemiological tactics, and self-identification to create a biosocial reality that serves values and ethical goals that are common in contemporary society. Researchers identify with and as minorities, thus interpreting their actions as aiding the cause of racial justice. At the same time, they are transformed by the research they produce. They practice a reflexive form of biosociality in which they actively work to refashion ideas based on the kind of biosocial future they want for society. Yet, in privileging a heuristic approach to taxonomy construction and investigation into race, researchers keep race at the center of genomic research. Further, they call for more research and research freedom within the field, so that genomics can one day solve society's problem of race. Instead of accepting oversight from the government, these researchers view the future as one where the field's biological knowledge about race will serve as a policy corrective and have broad hegemonic appeal.

While it is important that scientists acknowledge the political salience of race in their lives and their social worlds, there are problems with the reflexive biosociality discussed here. The case of race in genomics helps bring a number of issues into view. First, when scientists appeal to their own experience and understandings, partial or stereotypical ideas can be uncritically put to the efforts of research equality. Here, we have seen scientists creating ambivalent research practices with race, including rejecting official taxonomies while using personally valued lay categories to promote minority inclusion. Race stands to be reified as genetic whenever it is used to structure and communicate genomic research and evidence, therefore categories that are imported from the social sphere must be carefully explained and defined. Second, scientists can reproduce inequality by creating alternatives that are not so different. Even when scientists alter official taxonomies to disseminate corrective taxonomies, their taxonomies lend an imprimatur of science to what are still socially derived taxonomies. In these cases, genomic comparisons between socially constructed groups must be qualified. When scientists engineer taxonomy toward inclusionary purposes, awareness of the difference between genomic populations and social populations also must be maintained. Finally, by enacting a reflexivity focused more on the researcher's immediate social world, other spheres of value may go unaddressed. This leads to a narrowing of practice and a silencing of alternative strategies. This is most clear in the way the genomic paradigm has displaced sociological approaches to understanding race. Many scientists who take issue with the social inequalities of race never create measures for those very social inequalities, such as the quality of neighborhoods, living conditions, healthcare, and other aspects of the built environment. Even when scientists incorporate social epidemiological indicators, they focus on health behaviors, lifestyle, and other habits that ignore the broader social context of inequality.

At present, race consciousness is the ethical norm in genomics. This mirrors the path of identity politics in the U.S., as reflexivity has come to replace colorblindness. However race consciousness creates its own problems when it is practiced in the biomedical context, such as improper treatment and dubious associations between race and biomedicine, inaccurate conceptions of race and health disparities, the fixation of racial profiling in medicine, and the establishment of market incentives that cause harm (Epstein, 2007). Thus it is important that genomic biosociality, and all researcher biosociality, is carefully examined. With a clearer picture of the kind of sociality new avenues in biomedical research bring about, a more critical program of knowledge production can begin. Likewise, a greater understanding of the relationship between race and biosociality may set us on the path to a more just society.

\section{Acknowledgements}

I warmly thank the researchers who participated in this study. Orville Lee and Troy Duster provided helpful guidance through the research process. I am especially grateful to Ruha Benjamin, Lundy Braun, Phil Brown, Sarah Daynes, Adrián Lopez-Denis, Oz Frankel, Daniel Lee Kleinman, Deborah Levine, Aaron Panofsky, Deborah Weinstein, Vera Zolberg, and fellows of the Cogut Center for Humanities for careful readings. Thanks are also due to four anonymous reviewers. This research benefited from funding from the National Science Foundation, the Andrew Mellon Foundation, and the New School for Social Research.

\section{References}

(AAA), American Anthropological Association. (1998). Statement on "Race".

(CDC), center for disease control and prevention. 1993. Use of race and ethnicity in public health surveillance summary of the CDC/ATSDR workshop. 
(CDC). (1999). Federal Register, 64(46), 11915-11920, Mar 10.

(FDA), Food and Drug Administration. (1998). Investigational new drug applications and new drug applications.

(FDA), Food and Drug Administration. (2003). FDA issues guidance for collection of race and ethnicity data in clinical trials for FDA regulated products. In T03-07. Washington, DC

(FDA), Food and Drug Administration. (2005). Guidance for industry on the collection of race and ethnicity data in clinical trials for FDA regulated products.

(HHS), U.S. Department of Health and Human Services. (1998). Healthy people 2010 objectives: Draft for public comment. Washington, DC: HHS, Office of Public Health and Biomedicine.

(NIH), National Institutes of Health. (1993). The NIH revitalization act of 1993, Vol. PL, 103-143.

(NIH), National Institutes of Health. (2000). NIH guidelines on the inclusion of women and minorities as subjects in clinical research.

(NIH), National Institutes of Health. (2001). NIH policy on reporting race and ethnicity data: Subjects in clinical research.

(OMB), Office of Management and Budget. (1978). OMB directive no. 15. In race and ethnic standards for federal statistics and administrative reporting. statistical policy handbook. Washington, DC: OMB Publications Office.

Abu El-Haj, N. (2007). The genetic reinscription of race. Annual Review of Anthropology, 36, 18.

Angier, N. (2000). Do races differ? Not really, genes show. New York Times.

Bliss, C. (2009). Genome sampling and the biopolitics of race. In S. Binkley, \& J. Capetillo (Eds.), A foucault for the 21st century: Governmentality, biopolitics and discipline in the new millennium. Boston: Cambridge Scholars Publishing.

Bliss, C. (2012). Equality by DNA: Race activism and expertise among elite genome scientists. Palo Alto, CA: Stanford University Press.

Bamshad, M. (2005). Genetic influences on health: does race matter? Journal of the American Medical Association, 294, 937-946.

Bamshad, M. J., Wooding, S., Watkins, W. S., Ostler, C. T., Batzer, M. A., \& Jorde, L. B. (2003). Human population genetic structure and inference of group membership. American Journal of Human Genetics, 72, 578-589.

Bamshad, M., \& Guthery, S. L. (2007). Race, genetics and medicine: does the color of a leopard's spots matter? Current Opinion in Pediatrics, 19, 613-618.

Bolnick, D. A., Fullwiley, D., Duster, T., Cooper, R. S., Fujimura, J. H., Kahn, J., et al. (2007). The science and business of genetic ancestry testing. Science, 318, 2

Braun, L. (2002). Race, ethnicity, and health: can genetics explain disparities? Perspectives in Biology and Medicine, 45, 159-174.

Burchard, E. G., Ziv, E., Coyle, N., Gomez, S. L., Tang, H., Karter, A. J., et al. (2003). The Importance of race and ethnic background in biomedical research and clinical practice. New England Journal of Medicine, 348, 1170-1175.

Chandler, D. (2001). Heredity study eyes European origins. Boston Globe May, 10, A22

Collins, H. M. (1992). Changing order: Replication and induction in biomedical practice. Chicago: The University of Chicago Press.

Danto, A. C. (1985). Narration and knowledge: Including the integral text of analytica philosophy of history. New York: Columbia University Press.

Dunston, G. (2011). From the founding director. http://www.genomecenter.howard. edu/from_director.htm.

Duster, T. (2003). Statement of the American sociological association on the importance of collecting data and doing social biomedical research on race.

Epstein, S. (2007). Inclusion: The politics of difference in medical research. Chicago: University of Chicago Press.

Fujimura, J., \& Rajagopalan, R. (2011). Different differences: the use of 'genetic ancestry' versus race in biomedical human genetic research. Social Studies of Science, 41, 5-30.

Fullwiley, D. (2007a). Race and genetics: attempts to define the relationship. BioSocieties, 2, 221-237.

Fullwiley, D. (2007b). The molecularization of race: institutionalizing human difference in pharmacogenetics practice. Science as Culture, 16, 1-30.

Fullwiley, D. (2008). The biologistical construction of race: 'admixture' technology and the new genetic medicine. Social Studies of Science, 38, 695-735.

Goffman, E. (1959). The presentation of self in everyday life. New York: Double Day and Company.

Goldstein, A., \& Weiss, R. (2003). Howard U plans genetics database. Washington Post (May 28) A06.

Hermanowicz, J. C. (1998). The stars are not enough: Scientists: Their passions and professions. Chicago: University of Chicago Press.

Hermanowicz, J. C. (2009). Lives in science: How institutions affect academic careers. Chicago: University of Chicago Press.

Hinds, D. A., Stuve, L. L., Nilsen, G. B., Halperin, E., Eskin, E., Ballinger, D. G., et al. (2005). Whole-genome patterns of common DNA variation in three human populations. Science, 307, 1073.

Howard University. (2011). National human genome center. Retrieved 01.07.11. http:// www.genomecenter.howard.edu.

Hunt, L., \& Megyesi, M. (2008). The ambiguous meanings of the racial/ethnic categories routinely used in human genetics research. Social Science E Medicine, $66,349-361$.

Kahn, J. (2008). Exploiting race in drug development: BiDil's interim model of pharmacogenomics. Social Studies of Science, 38, 737-758.

Kumar, R., Seibold, M. A., Aldrich, M. C., Williams, L. K., Reiner, A. P., Colangelo, L. et al. (2010). Genetic ancestry in lung-function predictions. New England Journa of Medicine, 363, 321-330.

Lee, S. S. (2007). The ethical implications of stratifying by race in pharmacogenomics. Clin Pharmacol Ther, 81, 122-125.
Litt, I. F. (2001). When race matters. Journal of Adolescent Health, 29, 311.

Manolio, T. A., Bailey-Wilson, J. E., \& Collins, F. S. (2005). Genes, environment and the value of prospective cohort studies. Nature Reviews Genetics, 7, 812-820.

M'Charek, A. (2005). The human genome diversity project: An ethnography of biomedical practice. Cambridge; New York: Cambridge University Press.

McLeod, H. L. (2001). Pharmacogenetics: more than skin deep. Nature Genetics, 29 247-248.

Montoya, M. (2011). Making the Mexican diabetic: Race, science, and the genetics of inequality. Berkeley, CA: University of California Press.

Moore, K. (2008). Disrupting science. Princeton: Princeton University Press.

Morning, A. (2009). Toward a sociology of racial conceptualization for the 21st century. Social Forces, 87, 26.

Nature Genetics (2001). Genes, drugs and race. 29: 239-40.

Nature Genetics. (2004). The unexamined "Caucasian." 36: 541.

Nelson, A. (2008a). BioScience: genetic genealogy testing and the pursuit of African ancestry. Social Studies of Science, 38, 759-783.

Nelson, A. (2008b). The factness of diaspora. In B. Koenig, S. S.-J. Lee, \& S. S. Richardson (Eds.), Revisiting race in a genomic age. Piscataway: Piscataway.

Novas, C. (2006). The political economy of hope: patients' organizations, science and biovalue. BioSocieties, 1, 289-305.

Novas, C., \& Gibbons, S. (Eds.). (2007). Genetics, biosociality and the social sciences: Making biologies and identities. London: Routledge.

Novas, C., \& Rose, N. (2000). Genetic risk and the birth of the somatic individual. Economy and Society, 29, 495-513.

Office of the Press Secretary. (2000). Remarks by the President, Prime Minister Tony Blair of England (via satellite), Dr. Francis Collins, Director of the National Human Genome Research Institute, and Dr. Craig Venter, President and Chief Biomedical Officer, Celera Genomics Corporation, on the completion of the first survey of the entire Human Genome Project. Washington, DC: The White House.

Outram, S. M., \& Ellison, G. T. H. (2006). Anthropological insights into the use of race/ethnicity to explore genetic determinants of disparities in health. Journal of Biosocial Sciences, 38, 83-102.

Patil, N., Berno, A. J., Hinds, D. A., Barett, W. A., Doshi, J. M., Hacker, C. R., et al. (2001). Blocks of limited Haplotype diversity revealed by high resolution scanning of human chromosome 21. Science, 294, 1719-1723.

Petryna, A. (2002). Life exposed: Biological citizens after chernobyl. Princeton: Princeton University Press.

Rabinow, P. (1996). Essays on the anthropology of reason. Princeton: Princeton University Press.

Reardon, J. (2005). Race to the finish: Identity and governance in an age of genomics. Princeton: Princeton University Press.

Risch, N. (2006). Dissecting racial and ethnic differences. New England Journal of Medicine, 354, 408-411.

Rivara, F., \& Finberg, L. (2001). Use of the terms race and ethnicity. Archives of Pediatric and Adolescent Medicine, 155, 119

Rose, N. (2007). Politics of life itself: biomedicine, power, and subjectivity in the twenty-first century. Princeton: Princeton University Press.

Rothstein, M. A. \& Epps, P. G. (2001). Pharmacogenomics and the (ir)relevance of race. Pharmacogenomics Journal, 1, 104-108.

Schwartz, R. S. (2001). Racial profiling in medical research. New England Journal of Medicine, 344, 1392-1393.

Shapin, S. (2008). The scientific life: A moral history of a late modern vocation. Chicago: University of Chicago Press.

Smart, A., Tutton, R., Martin, P., Ellison, G. T. H., \& Ashcroft, R. (2008). The standardization of race and ethnicity in biomedical biomedicine editorials and UK biobanks. Social Studies of Science, 38, 407-423.

Steele, F. R. (2002). Genetic "differences. Genomics, 79, 145

Stoto, M., Behrens, R., \& Rosemont, C. (1990). Healthy people 2000: Citizens chart the course. Washington, DC: U.S. Department of Health and Human Services (HHS).

Tang, H., Quertermous, T., Rodriguez, B., Kardia, S. L. R., Zhu, X., Brown, A., et al. (2005). Genetic structure, self-identified race/ethnicity, and confounding in case-control association studies. American Journal of Human Genetics, 76 $268-275$

Torres, J. B., \& Kittles, R. A. (2007). The relationship between "race" and genetics in biomedical research. Current Hypertension Reports, 9, 196-201.

Tutton, R. (2007). Constructing participation in genetic databases: citizenship, governance, and ambivalence. Science, Technology, and Human Values, 32, 172-195.

Tutton, R., \& Corrigan, O. (2004). Genetic databases: Socio-ethical issues in the collection and use of DNA. London: Routledge.

UNESCO. (1950). The race question. Paris: UNESCO.

UNESCO. (1952). What is race? Paris: UNESCO.

Whitmarsh, I. (2008). Biomedical ambiguity: Race, asthma, and the contested meaning of genetic research in the Caribbean. Ithaca: Cornell University Press.

Williams, R. (1991). Base and superstructure in marxist cultural theory. In C. Mukerji, \& M. Schudson (Eds.), Rethinking popular culture: Contemporary perspectives in cultural studies. Berkeley: University of California Press.

Wilson, J. F., Weale, M. E., Smith, A. C., Gratrix, F., Fletcher, B., Thomas, M. G., et al. (2001). Population genetic structure of variable drug response. Nature Genetics, 29, 265-269. Winker, M. (2004). Measuring race and ethnicity: why and how? Journal of the American Medical Association, 292, 1612-1614.

Wood, A. J. (2001). Racial differences in the response to drugs-pointers to genetic differences. New England Journal of Medicine, 344, 1394-1396. 